\title{
Formative Factors of the Maria Åkerblom Movement
}

\author{
By GUSTAV BJÖRKSTRAND
}

The Akerblom movement exemplifies the best known impact on the cultural and religious environment of Swedish Finland, of a geographically and historically extensive phenomenon-the prophet movement. In spite of its proximity in time, some preparatory research has been carried out on the subject, even if a special study is still lacking. ${ }^{1}$

An obvious prerequisite for the emergence of a prophet movement is the prophet figure. The character and development of the movement are, to a great extent, dependent on the background and personality of this figure. The adolescence of Ida Maria $\AA$ kerblom (IM $\AA$ ), a cottar's daughter, born in Snappertuna in rural West Nyland in 1898 , was both materially and spiritually barren. Youngest but one in a family of nine children, she was a late developer and of a sickly constitution. The strong feeling of insufficienc $y^{2}$ she developed should be seen against the background of extremely poor home conditions, lack of intellectual stimulation-although clearly gifted, she was unable to go to school for more than a few weeks-and her status of foster-child from the age of five until her teens. Even as a child, she attempted to compensate for this feeling of inferiority by an hysterical behaviour pattern. She caused conflicts incessantly in her relationships with older people and tried to force her contemporaries into a position of subordination. When reality proved inflexible to the dictates of her will, she superimposed her role in dreams and visions. ${ }^{3}$

In matter of religion, she grew up in an atmosphere of piety best described as 'traditional and formalistic', with elements of evangel istic and later, also Anglo-Saxon revivalist piety.

On February 22nd 1917, the day on which IM $\AA$ 's confirmation priest and

\footnotetext{
1 The author will publish, within the near future, a dissertation on the movement. As far as currently available literature is concerned, cf. Voipio, 1928, $135 \mathrm{ff}, 1951,32 \mathrm{ff}$, and lit. cited there; also Ostarhild, $27 \mathrm{ff}$. On the religio-psychological interpretation of IMÅ; cf. Björkhem, 1940, 392 ff, and 1942, $50 \mathrm{ff}$, and Arbman, $200 \mathrm{ff}, 219 \mathrm{f}, 227$.

2 The term is taken from Alfvén, 35. Cf. Björkhem 1940, $372 \mathrm{f}$.

${ }^{3}$ Cf. Alfvén, 43 ff; Björkhem 1940, 372 f.
} 
the curate at Snappertuna, Karl-Erik Lind ström died, IM $\AA$ assumed the role of prophet and preacher, according to her account, after a severe illness. Lying in bed, she prophesied, while in a somnambulic state, imminent periods of hardship, and depicted her heavenly visions. ${ }^{4}$

Throughout her active period, IM $\AA$ was a typical representative of the group categorised by John Björkhem as C-hysterics. ${ }^{5}$ Her need for selfassertion would not yield for authority or any other measures. She was egocentric, impatient, vulnerable, emotionally self-indulgent, but also hard, irreconcilable, morally indifferent and endowed with a vivid and colourful imagination. In a somnambulic state, a radical transformation of her personality occurred. In her role of prophet, her performance was dramatically assured and faultless. She modulated at an early stage, to use Andrae's terminology, ${ }^{6}$ from the personally inspired type to the dynamic, in whom divine inspiration and personal conviction become one and the same. If transfer of property, perjury or murder were necessary to protect her position, she announced these as God's will.

That IM $\AA$ 's claims of being the prophet of the Lord were credited, must be seen against the background of her youth, and, as experienced by her audiences, charismatic qualities manifested in prophecies the ability to read thoughts and reveal hidden objects, as well as in faith-healing.

The history of the movement falls into four main phases: the Origins 1917-1920, Consolidation 1920-1923, the Struggle 1923-1927 and Dissolution 1927-.

\section{Origins 1917-1920}

IM $\AA$ began her activity during the year in Finnish history that has been called the year of madness, "Hullu vuosi" -1917 , when the entire traditional social fabric was tottering as a result of the Russian revolution, and nobody knew what the future had in store. ${ }^{7}$ The reason why people flocked to IM 's meetings, not merely in hundreds but in thousands, is to be found in the insecurity induced by the upheavals of the time, and the highly remarkable factors of IM $\AA$ 's background, youth and sex, as well as her dramatic way of interpreting her prophetic role. When external conditions were

\footnotetext{
${ }^{4}$ IM $\AA$ has recounted her experiences in her autobiography published by Variovaara, cf.

Åkerblom, Maria, $1 \mathrm{ff}$.

${ }^{5}$ Cf. Björkhem 1942, 50 ff.

${ }^{6} \mathrm{Cf}$. Andrae, $212 \mathrm{f}$.

${ }^{7}$ On this, cf. e.g. Jutikkala, $249 \mathrm{ff}$.
} 
stabilised after the civil war, IM $\AA$ 's role of preacher in Nyland was played out, with the exception of a small circle in Helsinki, where she was able to join the movement of a previous sleeping preacher, and thereby win a firmer footing for her work.

In Ostrobothnia, IM connected herself with a revivalist piety that was individualistic and subjectivistic, and characterised by the ecclesiola idea and a conscious demarcation from the outer world redolent of Pietism. In Kokkola and surrounding districts, there is evidence of a reformist AngloSaxon influence in the emphasis on the day of reckoning, the winning of souls, and the interdenominational character. There were also elements of an ecstatically informed mysticism with marked antinomian elements and strongly allegorical biblical interpretation. In Teerijärvi, the second parish where IM $\AA$ 's preaching gained a response, the parish was sharply divided into evangelical and pietistic factions, where the pastor represented the evangelical revival. In both parishes there were associations where her prospective followers could appropriate the leadership: the Young Christians' Union in Kokkola_-an offshoot of the older local Young People's Christian Association and in Teerijärvi, Teerijärvi's Christian Young People's Union, deriving immediately from the pietistic revival, but later also marked by Anglo-Saxon influence. IMA's activity, 1918-1921, in Kokkola and Teerijärvi, gave rise to a strong revival best characterised as an echo of the great nineteenth century popular revivals in the area. The new element was that IM $\AA$, in her capacity of prophet, was believed to communicate direct revelations from God, at first in a somnambulic state, but later also whilst fully awake. In both Kokkola and Teerijärvi, the regular clergy opposed the revival strongly, but with little success. The more lasting results of IM $\AA$ 's activity here, must be seen against the background of the religious structure of these parishes, as well as the presence of organisations that could be taken over by followers, thus offering further scope for continued work.

An interesting detail is that in spite of various attempts, IM $\AA$ was unable to win any followers in the parishes of Nedervetil and Kronoby, situated between Kokkola and Teerijärvi, and south of Teerijärvi respectively. The explanation is probably that pastoral leadership was not queried here, and that there was therefore no need for a new leader figure; neither were there any associations in existence which IM $\AA$ could join to organise her work. 


\section{Consolidation 1920-1923}

Those indifferent to religion in Kokkola and its surroundings had noticed with increasing irritation how the movement was gaining increasing ground. They saw too, with what devotion and self-sacrifice followers in their hundreds supported the morally and ethically deficient leadership, as it was considered, of IM $\AA$ and her foster-father of a year's standing, forester E. R. Vartiovaara, who had both settled in Kokkola in the spring of $1919 .{ }^{8}$ References were made to IM $\AA$ 's nightly meetings with predominantly male audiences, her relationship with Vartiovaara who had been the cause of a divorce case, her gallops on horseback through the streets of the town, and some instances of mental derangement that had occurred in connection with the activities of her movement. This group received support for its views from the regular clergy, and from Archbishop Gustaf Johansson who, during a visitation, sharply condemned the movement. ${ }^{9}$ There was an ever growing determination to remove the IM $\AA$-Vartiovaara "stain" from the place, something the temporary pastor in Kokkola had, with the help of the police attempted to do shortly after IM $\AA$ 's arrival in the town. The first opportunity that presented itself-the severe flogging of a young boy employed as IM $\AA$ 's groom-led to a riot in the town and the trial of the movement's leaders. The movement retaliated by suing the temporary pastor for libel, and later, by charging some of the leading figures in the opposite camp with the instigation of the riot. During these hostilities, followers underwent enforced separation and a process of consolidation, by the swearing of an oath of allegiance to the movement, so that its secrets would not be betrayed, and were driven to economic transactions, as a result of which, they became completely dependent on each other. During this period, the opposition organised a counter-movement by founding the Friends of the Church Association. Both groupings had about 500 members.

When, in the autumn of 1922 , IM $\AA$ thoughtlessly fired a shot at a person she believed to be hostilely disposed, this became the source of renewed attempts to drive the leader of the movement from the place. For her followers, it was again a matter of choice between somehow absolving IM $\AA$ from charges, or admitting to opponents that she constituted a danger to society. The decision to try to rehabilitate IM $\AA$ by using false witnesses led

\footnotetext{
${ }^{8}$ For parallells to the IM $\AA-V$ artiovaara relationship, cf. Björkhem 1940, $412 \mathrm{ff}$.

${ }^{9}$ On Gustaf Johansson's personality and theology, cf. Tiililä, $75 \mathrm{ff}$.
} 
to prosecutions for perjury. In order to save those charged with perjury, several dozen new testimonies were necessary, these also to be made under oath. The final consolidation took place in preparation for the so-called Grand Perjury Trial. "The Band of the Lord" as the movement called itself, was divided into three circles, and followers, after tests of obedience, were ranged in twelve grades. At the same time, the banks terminated all loans to members of the movement, which left members economically destitute and completely dependent on each other's help and support. Through this process of consolidation, the Band of the Lord, economically interdependent, loyal to the leadership, and convinced of their divinely righteous method of action as God's "arm of vengeance", were ready to go forth to the struggle for what, for them, meant more than property, honour, time, and the ties of friendship or family.

\section{The Struggle 1923-1927}

The attempts of followers to save those charged with perjury by means of new testimony could not prevent their being defeated at the trial. This defeat, combined with economic difficulties and constant persecution, enforced their departure from Kokkola and Teerijärvi, where the struggle was not carried on with the same intensity. But this did not merely signal the breaking up of the leadership, as opponents of the movement had imagined; the whole group, in fact, of about 200 people sold everything they still possessed and left for an obscure destination, hinted to be Palestine. In Helsinki, the first stage of the journey, the movement became involved in fresh litigation, and for this reason the journey proceeded no further.

When it became obvious to followers of the movement that the bailiff in Kokkola intended to prosecute another seventy of their number for perjury, the leadership saw the elimination of the governor as a necessary stage in a victorious struggle. The unsuccessful murder attempt led to a new citizens' meeting at Kokkola and deputations to the Ministry of the Interior, the Attorney General and the High Court. On the initiative of the Ministry of the Interior, a survey of the activities and plans of the movement was conducted as carefully as its hermetic nature permitted. On the basis of this investigation and defections by a couple of leading figures within the movement, the police were able to bring the leaders of the movement to account for the in- 
stigation of 46 cases of perjury, and the planning of the murder attempt; they were sentenced in 1927 to long periods of imprisonment.

That members of the movement-previously known as godfearing and irreproachable-could accept such a development within the movement, must be seen in the light of their unshakable conviction that IM $\AA$ was a prophet through whom God spoke directly. Thus, all actions, including murder attempts, perjury and thefts were justified by the bible. The band was God's arm of vengeance through which, in the struggle of the Final Days, He would accomplish his work. One must also take into account the physical and psychic terror used within the movement to inculcate the need for absolute loyalty and obedience.

\section{Dissolution 1927-}

The defeat of 1927 did not bring about the immediate dissolution of the movement, as had been generally expected. The explanation for this lies in the fact that, within the movement, the battle was not considered definitely lost; social intercourse with those who were like-minded strengthened faith, and "the Band of the Lord" still represented the only possibility of continued existence, not least from the economic point of view. ${ }^{10}$

During the years when the leaders were imprisoned, their followers lived an isolated, communal life at Toivola, the name of the house where the majority of the movement's members lived. Here, an internal development took place however, the results of which appeared in connection with the splitting of the movement in 1932 , shortly before the release of IM $\AA$. In connection with the schism, two thirds of the members left Toivola and gradually became integrated into society and Lutheran Evangelical parish work. The reasons for the split are to be found in the fact that links with IM $\AA$ were weakened during her long absence, and that a revival at Toivola revealed to the leaders who had returned that IM $\AA$ was not a necessary mediator for the success of God's work. Above all, the split was conditioned by the fact that the fundamental idea of the movement, of IM $\AA$ as a mediator of direct visions from God, was finally broken by another sleeping preacher, Hilda Hottis' appearances before the group. She preached that IM $\AA$ was a false prophet, and in face of contradictory prophecies, their critical sense of prophetic pronouncements in general was aroused.

\footnotetext{
${ }^{10} \mathrm{Cf}$. Festinger, $216 \mathrm{ff}$.
} 
Those who remained at Toivola interpreted the split in terms of IM $\AA$ 's prophecies of a time of sifting, and preferred to await her return, in order not to judge her unheard. After her stay in prison, IM $\AA$ was no longer able to assume her role of preacher, in spite of various attempts, and she transferred her attentions to business activities where she had great success. That the dissolution of her band proceeded so slowly-it is still not quite complete-can be explained by its strict internal control, reinforced by fear of new disclosures and ensuing court cases, the limited possibilities of creating a future outside the movement, and personal difficulties in surrendering convictions for which one has sacrificed belongings, reputation, time and ties of friendship.

The emergence of the $\AA$ kerblom movement must be viewed as the result of several concurring circumstances: IM $\AA$ 's complicated personality, the religious structure of the Helsinki circle and in Ostrobothnia, together with the unrest and insecurity of the time. The development from revivalist movement to criminal sect was a result of the increasingly violent aggressive behaviour of two opposing parties. The dissolution of the movement was brought about by the undermining of belief in IM $\AA$ as a direct mediator of divine revelation, as a result of her long stay in prison. The belief was ultimately destroyed for the majority of her supporters in connection with the activities of another sleeping preacher. The continued disintegration was a result of the secularisation of the sect and a gradual relaxation of its uncommunicativeness with the outer world, a trait that seems natural in the light of the sect's extensive criminal activity.

\section{Bibliography}

Alfvén, J., 1933, Hysterien och dess psykologiska struktur. Stockholm.

Andræ, T., 1968, Mystikens psykologi. Stockholm.

Arbman, E., 1970, Ecstasy or religious trance 3. Stockholm.

Björkhem, J., 1940, Antoinette Bourignon. Diss. Uppsala. Lund.

- 1942, De hypnotiska hallucinationerna. Diss. Lund.

Festinger, L. et al., 1956, When prophecy fails. Minneapolis.

Jutikkala, E., 1962, A History of Fin land. London.

Ostarhild, F., 1936, Schlafprediger in Finnland. Göttingen.

Tiililä, O., 1963, Features of New Systematic Theology in Finland. Finnish Theology Past and Present. Theologia Fennica 7. Finnish Theological Literature Society 73. Helsinki.

Voipio, A., 1928, Folkpredikanter och falska profeter. Helsingfors.

- 1951, Sleeping Preachers. Annales Academiae Scientiarum Fennicae B, 75,1. Helsinki.

Åkerblom, Maria, 1920, Maria Åkerbloms autobiografi och första delen av hennes verksamhet. Kokkola. 